\title{
BIBLIOGRAPHICAL RECORD.
}

(Continued from page 248.)

The date of publication, here given in brackets [ ], marks the time at which the work was received by the Editor, unless an earlier date of publication is known to him. An asterisk * before a title is the Recorder's certificate of accuracy of quotation. Corrections of errors and notices of omissions are solicited. - B. Pickman Mann.

Nos. 1188 to 1266 are from Can. entom., 1877, v. 9.

* 1188. Edwards, W: H: Notes on Limenitis proserpina and arthemis. (Can. entom., 1877, v. 9, p. 114.)

$L$. arthemis and L. proserpina raised from eggs of L. proserpina; geographical distribution of the latter species. [July, 1877.]

* 1189. Grote, A: Radcliffe. A new genus and species of Geometrae. (Can. entom., 1877, v. 9, p. 114-115.)

Describes Meskea, n. g., and M. dyspteraria n. sp., from Texas. [July, 1877.]

* 1190. Bailey, James Spencer, M. D. Center, N. Y., entomologically considered. (Can. entom., 1877, v. 9, p. 115-119.)

Location and character of the place; list of 57 butterflies and 39 moths captured there. [July, 1877.]

* 1191. Bunker, Robert. Notes on the food plant of Hemileuca maia. (Can. entom., 1877, v. 9, p. 119.)

Character of the region inhabited by Hemileuca maia; eggs laid on Aster and on Quercus. [July, 1877.]

* 1192. Grote, A: Radcliffe. Correspondence. (Can. entom., 1877, v. 9, p. 119-120.)

Mention of a few lepidoptera caught in camp at Lake Forest, Erie co., N. Y., 7 June, 1877. [July, 1877.]

* 1193. Edwards, W: H: Correspondence. (Can. entom., 1877 , v. 9, p. 120.)

Edwards' name "Lintneria" for a genus of Hesperidae preoccupied by Butler for a genus of Sphingidae; replaced by "Systasea" Butl. [July, 1877.]

* 1194. Bunker, Robert. Effect of hot weather upon the transformation of the sphinxes. (Can. entom., 1877, v. 9, p. 120.)

Philampelus satellitia buried itself 31 July, pupated 1 Aug., imaginated 10 Sept., which "would seem to show that this species in a warm climate would become double brooded." [July, 1877.]

* 1195. Bassett, Homer Franklin. Remarks upon the Cynipidae. (Can. entom., 1877, v. 9, p. 121-122.) 
The offspring of the bisexual generation of certain speciea is exclusively female ; it is judged that the offspring of the unisexual generation is the bisexual one. [Aug., 1877.]

* 1196. Chambers, Vactor Tuusey. Tineina. (Can. entom., 1877, v. 9, p. 123-127.)

Describes Gracilaria (Corisceum) quinquenotella n. sp. ; remarks upon five other species of Gracilaria. [Aug., 1877.]

* 1197. Siewers, C: Godfrey. Notes on larvae - Fondness for water - Hints to beginners. (Can. entom., 1877, v. 9, p. 127-129.)

Some larvae need water to drink; habits of certain species ; methods of rearing insects. [Aug., 1877.]

* 1198. Lintner, Joseph Albert. On a new species of Cossus. (Can. entom., 1877, v. 9, p. 129-130.)

Describes Cossus centerensis n. sp., from Center, N.Y. [Aug., 1877.] [The name of this author is given wrongly in Rec., no. 1049, 1097.]

* 1199. Grote, A: Radcliffe. Notice of Mr. Butler's Revision of the Sphingidae. (Can. entom., 1877, v. 9, p. 130133.)

Notes, mostly synonymical, upon the work cited; describes Eusmerinthus n. g. (type : Smerinthus geminatus). [Aug., 1877.]

* 1200. Couper, W: List of Canadian diptera. (Can. entom., 1877, v. 9, p. 133-135.)

List of 143 species, compiled from British Museum catalogs for 1848 and 1849. [Aug., 1877.]

* 1201. Grote, A: Radcliffe. A new Plusia allied to hochenwarthi. (Can. entom., 1877, v. 9, p. 135-136.)

Describes P. sackenii n. sp., from Colorado. [Aug., 1877.]

* 1202. [Saunders, W:] Book notices. (Can. entom., 1877, v. 9, p. 137-138.)

Notice of Murray's Economic entomology - Aptera ; of Riley's 9th Annual report ... Missouri [See Rec., No. 970] ; of Hill's photograph of Harpalus caliginosus. [Aug., 1877.]

* 1203. Moffat, J: Albert. An instance of retarded development. (Can. entom., 1877, v. 9, p. 138-139.)

An interval of over 20 months elapsed from the formation of the cocoon to the emergence of the imago of [Cimbex americana]. [Aug., 1877.]

* 1204. Pearson, G: W., jr. Melitaea phaeton. Can. entom., 1877, v. 9, p. 139.)

Melitaea phaeton very abundant at Montreal and at Ottawa, Canada, in the summer of 1877. [Aug., 1877.] 
* 1205. Bell, James Thompson. How to destroy cabinet pests. (Can. entom., 1877, v. 9, p. 139-140.)

Successful use of potassic cyanide (KCN). [Aug., 1877.]

* 1206. Zimmerman, C: Diehl. [Meloe angusticollis.] (Can. entom., 1877, v. 9, p. 140.)

Meloe angusticollis feeding on Anemone japonica. [Aug., 1877.]

* 1207. Moffat, J: Albert. Limenitis proserpina. (Can. entom., 1877, v. 9, p. 140.)

Limenitis proserpina taken very rarely at Hamilton, Ont., and always in connection with $L$. arthemis. [Aug., 1877.]

* 1208. Peck, G: W. Captures at sugar. (Can. entom., 1877, v. 9, p. 140.)

Capture of Ellibia versicolor, Everyx choerilus and E.myron, at Morristown, N. J. [Aug., 1877.]

* 1209. Dobree, W. T. Agrotis fennica wanted. (Can. entom., 1877 , v. 9 , p. 140. )

Petition for specimens of $A$. fennica. [Aug., 1877.]

* 1210. Edwards, W: H: On the preparatory stages of Satyrus nephele. (Can. entom., 1877, v. 9, p. 141-143.)

Describes the egg, larva at all stages, and pupa and habits of the larva of Satyrus nephele. [Aug., 1877.]

* 1211. Bruner, Laurence. List of Acrididae found in Nebraska. (Can. entom., 1877, v. 9, p. 144-145.)

List of 95 species. [Aug., 1877.]

* 1212. Chambers, Vactor Tousey. Tineina. (Can. entom., 1877 , v. 9, p. 145-147.)

Notes on one or more species related to Batrachedra striolata, and on Perimede erransella. [Aug., 1877.]

* 1213. [Dodge, C: Richards.] Ravages of white ants. (Field and forest, 1877, v. 3, p. 17.) (Can. entom., 1877, v. 9, p. 147.)

Books eaten by Termes in Liberia. [July, 1877.]

* 1214. Bethune, C: J. S., compiler. Insects of the northern parts of British America. From Kirby's Fauna boreali-americana: Insecta. (Can. entom., 1877, v. 9, p. 148-156.)

[Cont. from v. 7, p. 159; see Rec., no. 485.] Reprint of p. 257-270 of Kirby's work, comprising descriptions of 19 species of hymenoptera, with notes by the compiler. [Aug., 1877.] 

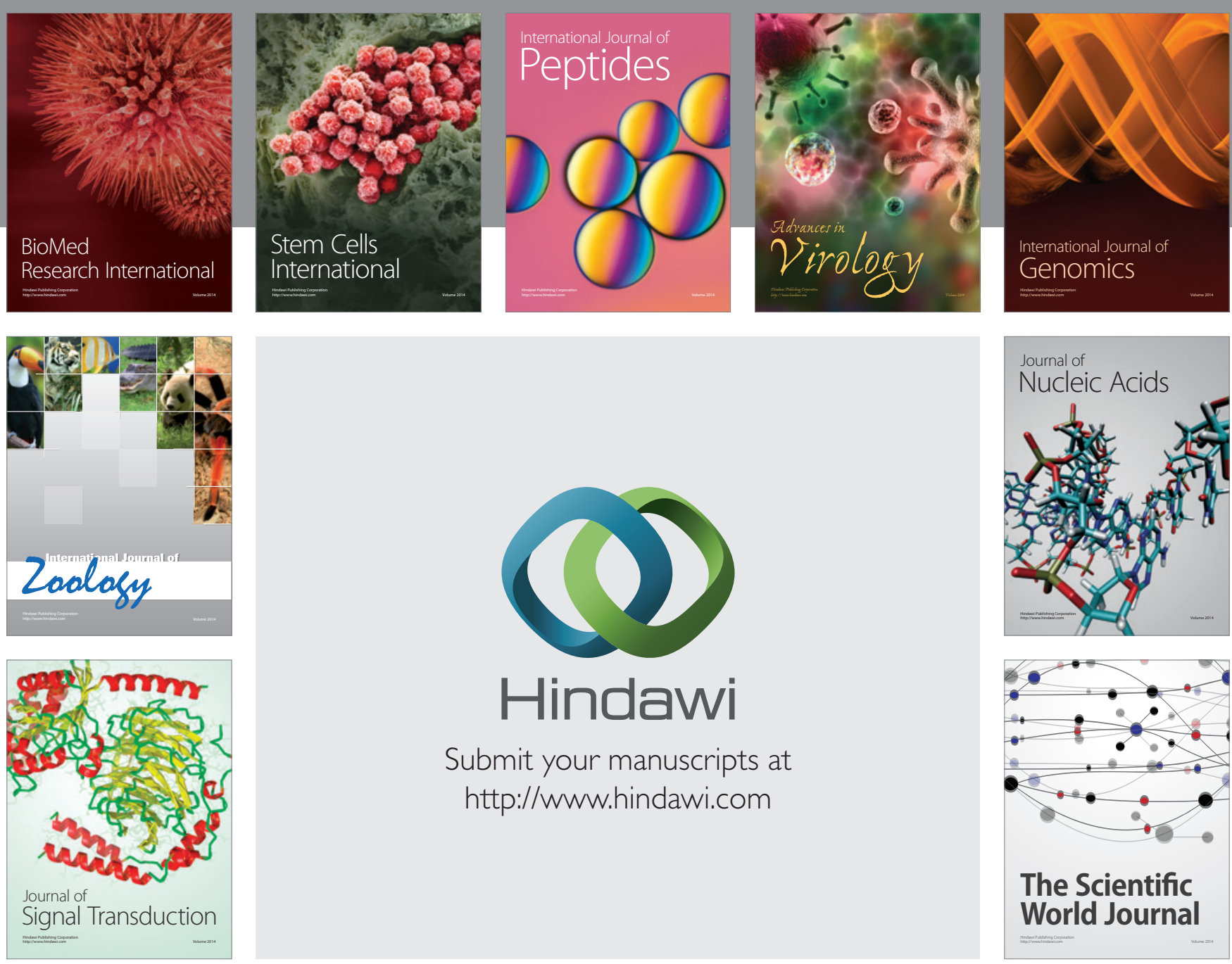

Submit your manuscripts at

http://www.hindawi.com
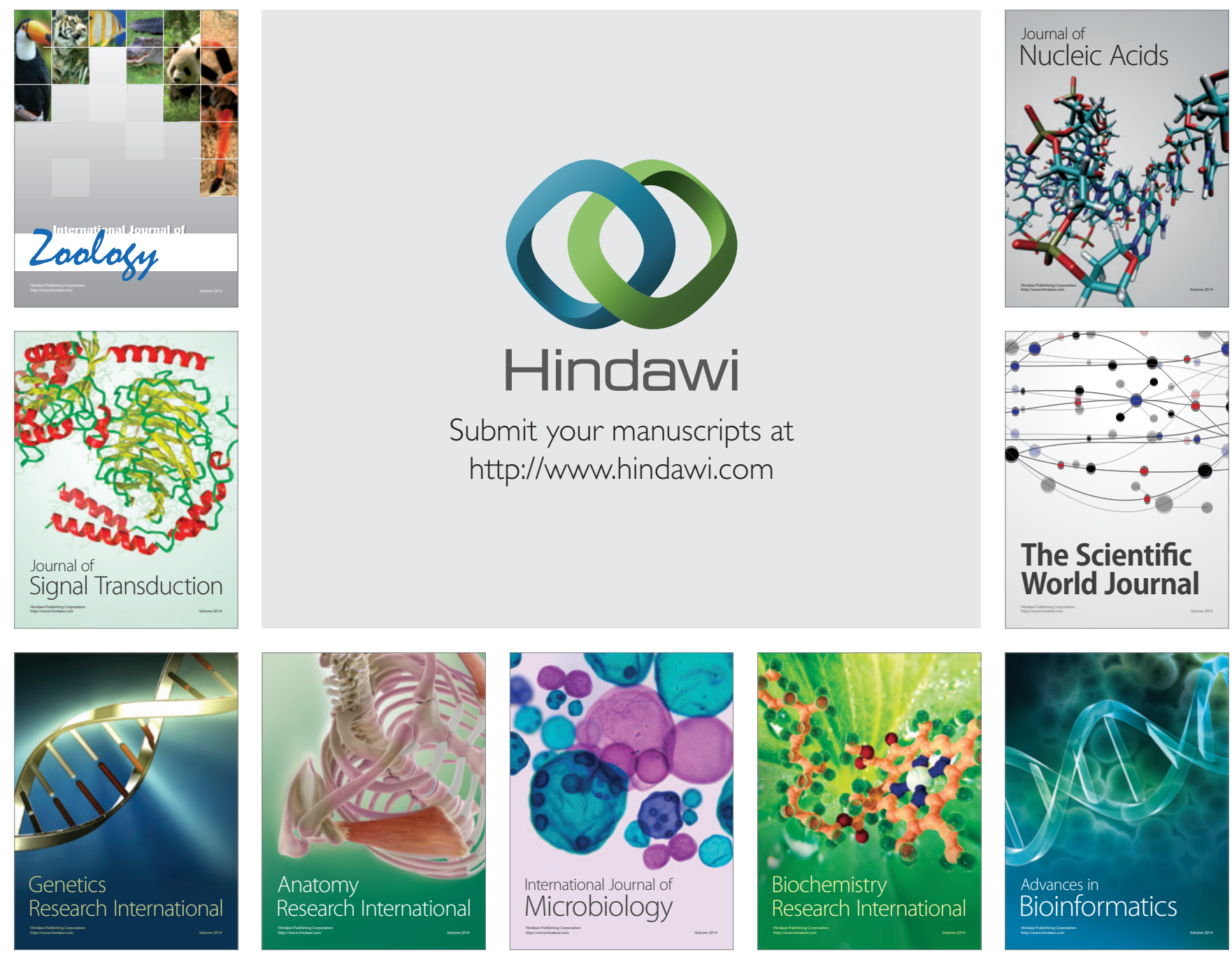

The Scientific World Journal
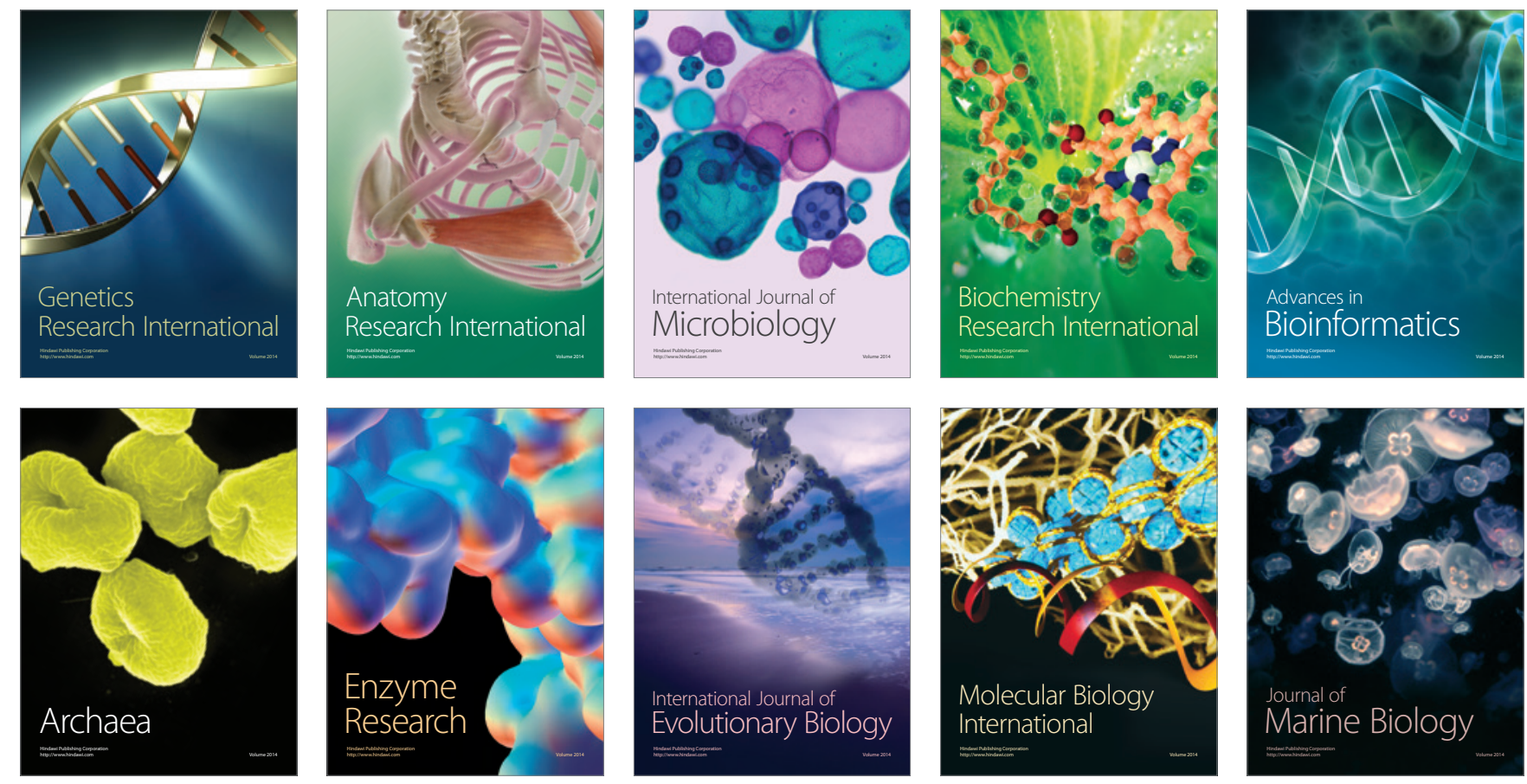